\title{
Development of Novel Method for the Estimation of Total Cholesterol in Chicken Eggs
}

\begin{abstract}
Background: Cholesterol estimation in eggs was mostly done by High performance liquid chromatography (HPLC) and gas chromatography which are tedious, expensive and time consuming methods. Thus, there is a need to determine cholesterol content by an easy spectrophotometric method which is not expensive and tedious. The present study was aimed to determine the cholesterol content in chicken eggs spectrophotometrically so as to provide better information about the nutritional quality of an egg

Methods: The experiment was conducted on 24 healthy layer birds of Dahlem Red (DR). 45 egg samples were randomly collected fresh in the morning. Total cholesterol was determined by enzymatic colorimetric method by using biochemical estimation kit (Agappe Diagnostics Ltd.). The pure yolk was separated and determined enzymatically for cholesterol estimation. The method is newly evaluated, rapid, simple and accurate.

Result: The methodology designed herein can provide specific, accurate and suitable method for estimation of total cholesterol in chicken eggs. The average cholesterol content of Dahlem red was $12.59 \pm 0.09 \mathrm{mg} / \mathrm{ml}$ in egg yolk or $195.66 \pm 2.80 \mathrm{mg} / \mathrm{egg}$ yolk.
\end{abstract}

Key words: Cholesterol, Coronary diseases, Dahlem red, Spectrophotometric.

\section{INTRODUCTION}

An avian egg is a highly integrated biological system. The nutritive value and functional properties of an egg makes it an important item in human diet. Eggs and egg products form an integral part of the food chain. It is the only animal protein source in developing countries that is available to the general population in affordable price. Egg is source of protein, liposoluble vitamins A, D, E, K, vitamin B-complex such as cyanocobalamin, thiamine, riboflavin, niacin and pyridoxine. Among minerals; it contains iron, calcium, potassium, sodium, phosphorous and zinc. Egg is also an important source of dietary cholesterol which increases serum cholesterol that ultimately causes the appearance of coronary diseases. Egg contains good and bad cholesterol. The consumption of cholesterol rich food by diabetic patients, cancer carriers and hypercholesterolemia patients can raise the risk of coronary diseases (Aquino et al. 2010). The association of cholesterol with coronary diseases has raised the concerns by the consumer and somewhat lowered it's consumption in a certain section of society (Bragagnolo et al. 2002).

Dahlem Red is a brown egg-laying layer chicken which was donated to India for introduction to tropical layer production. It gained more importance for rural poultry production because of the coloured plumage and brown colour of the egg and is now being utilized as a female line for producing egg type chicken for free-range conditions (Panda et al. 2012). Dahlem red is known for its high disease tolerance and immune competence (Kundu et al. 1999). The present study is focused on determining total cholesterol content in chicken eggs.

Simple and easy methods were not available for cholesterol estimation which is an important area of interest
Department of Veterinary Physiology and Biochemistry, College of Veterinary and Animal Sciences, Chaudhary Sarwan Kumar Himachal Pradesh Agricultural University, Palampur-176 062, Himachal Pradesh, India.

Corresponding Author: Suruchi Sharma, Department of Veterinary Physiology and Biochemistry, College of Veterinary and Animal Sciences, Chaudhary Sarwan Kumar Himachal Pradesh Agricultural University, Palampur-176 062, Himachal Pradesh, India.

Email: suruchis91@gmail.com

How to cite this article: Sharma, S., Singh, G., Vij, R. (2021). Development of Novel Method for the Estimation of Total Cholesterol in Chicken Eggs. Asian Journal of Dairy and Food Research. DOI: 10.18805/ajdfr.DR-1780.

Submitted: 05-07-2021 Accepted: 11-10-2021 Online: 03-11-2021

as higher cholesterol content is directly related with artherosclerosis and coronary diseases. In the earlier method, total lipids were extracted with chloroform: methanol 2:1 forming a biphasic layer according to modified Folch method (Folch et al. 1957, Washburn and Nix, 1974 and Washburn, 1989). Then, chloroform extract is taken to estimate cholesterol by colorimetry method (Aquino et al. 2010). Hexane is used for extraction of unsaponifiable matter. Hexanic extract with acetic acid saturated with ferrous sulphate and then concentrated sulphuric acid is used to estimate cholesterol spectrophotometrically. In this method cholesterol estimation is compromised as hexane interferes with cholesterol because it is a chemical method and thus cholesterol is underestimated. Methods such as HPLC and gas chromatography are highly sophisticated and other chemical methods are not much reliable. Estimation of cholesterol in eggs was done spectrophotometrically and 
showed the values within the range and the procedure was found easy and less time consuming.

\section{MATERIALS AND METHODS Experimental birds}

Total 45 egg samples were randomly collected fresh in the morning. The study was carried out during the period of February 2019 to June 2020, in the Department of Veterinary Physiology and Biochemistry, College of Veterinary and Animal Sciences, Palampur. Total twenty four healthy layer birds of Dahlem Red breed of 30-32 weeks of age were reared under deep litter system in separate pens with nest boxes and were offered ad libitum drinking water and standard layer feed presented in Table 1.

\section{Sample preparation}

The egg was broken on a flat surface and was allowed to stand for five minutes. Carefully albumen and yolk were separated and yolk was transferred and rolled on Whatmann filter paper No. 1 to remove all the sticking albumen residues and chalazae. Pure yolk was poured in the graduated beaker after rupturing the yolk membrane with rat tooth forceps. Volume of yolk was recorded. The sample solution was prepared by diluting $100 \mu \mathrm{l}$ of yolk sample with $100 \mu \mathrm{l}$ of distilled water and mixing well using a vortex mixer. From diluted yolk sample $10 \mu$ of yolk sample was taken for estimation.

\section{Principle of cholesterol estimation}

Total cholesterol was determined by enzymatic colorimetric method (cholesterol oxidase peroxidase method) (Arntz et al. 1979; Fleg, 1973; Siedel et al. 1981 and Allain et al. 1974) using biochemical estimation kit (Agappe Diagnostics Ltd.). This method was based on the principle that free cholesterol and fatty acids are formed by the hydrolysis of cholesterol ester by cholesterol esterase. Free cholesterol is further oxidized by cholesterol esterase into 4-cholesten3-one and hydrogen peroxide. Hydrogen peroxide reacts with phenol and 4-aminoantipyrine in the presence of peroxidase to form a red coloured quinoneimine dye complex. Intensity of colour formed is directly proportional to the amount of the cholesterol present in the sample.

\section{Method of cholesterol estimation}

Cholesterol estimation kit contained 2 types of reagents. The first reagent contained Pipes buffer $(\mathrm{pH} \mathrm{6.9)}-50 \mathrm{mmol} / \mathrm{L}$, phenol- $24 \mathrm{mmol} / \mathrm{L}$ and sodium Cholate- $0.5 \mathrm{mmol} / \mathrm{L}$. The second reagent contained cholesterol esterase- $>200 \mathrm{U} / \mathrm{L}$, cholesterol oxidase- $>250 \mathrm{U} / \mathrm{L}$, peroxidase- $>1000 \mathrm{U} / \mathrm{L}$ and 4 amino antipyrine- $0.5 \mathrm{mmol} / \mathrm{L}$. A working solution was prepared by dissolving the content of first reagent with equal content of second reagent. The standard solution was prepared by mixing $1 \mathrm{ml}$ of working reagent with $10 \mu \mathrm{l}$ of cholesterol standard which was provided in the kit. The test solution was prepared with $1 \mathrm{ml}$ of working reagent and 10 $\mu \mathrm{l}$ of egg yolk sample. The blank was prepared by taking 1 $\mathrm{ml}$ of working reagent. The blank, standard and test solutions were incubated at $37^{\circ} \mathrm{C}$ for 5 minutes. Total cholesterol was estimated by recording absorbance of standard, test against blank at a wavelength of $505 \mathrm{~nm}$ by using biochemical estimation kit (Agappe Diagnostics Ltd.) in a semi-automated clinical chemistry analyzer (Microlab 300) based on the above principle. Finally, $\mathrm{mg} / \mathrm{ml}$ cholesterol in egg yolk was estimated by multiplying with the dilution factor. Cholesterol values in $\mathrm{mg} / \mathrm{egg}$ yolk, cholesterol values in $\mathrm{mg} / \mathrm{ml}$ in egg yolk and yolk volume are presented in Table 2.

\section{Statistical analysis}

The results obtained were analyzed for calculating mean \pm standard error.

\section{RESULTS AND DISCUSSION}

The egg yolk volume of Dahlem Red was $15.54 \pm 0.21 \mathrm{ml}$ and the average cholesterol content of Dahlem red egg in our study was $195.66 \pm 2.80 \mathrm{mg} / \mathrm{egg}$ yolk or $12.59 \pm 0.09 \mathrm{mg} /$ $\mathrm{ml}$ in egg yolk. Egg yolk cholesterol by gas liquid chromatography was $11.5-11.8 \mathrm{mg} / \mathrm{g}$ egg yolk in White Leghorn and $13 \mathrm{mg} / \mathrm{g}$ egg yolk in Rhode Island Red (Maurice et al. 1994) which was lower and almost within the present observed range, respectively. Egg yolk cholesterol by gas chromatography was $23.4 \pm 1.7 \mathrm{mg} / \mathrm{g}$ egg yolk in laying hen at 21 weeks of age and $20.4 \pm 1.6 \mathrm{mg} / \mathrm{g}$ egg yolk in laying hen at 56 weeks of age (Nielsen, 1998) which were higher than the present observed range. The egg yolk cholesterol levels in most of the poultry breeds were $180-190 \mathrm{mg}$ in egg yolk (Naviglio et al. 2012) and present results are reliable.

Egg yolk cholesterol value by method of Ingr and Simeonová (1983) using the Bio-La-test and the photometric detection based on Liebermann Burchard reaction was $153.45 \pm 12.39 \mathrm{mg} / \mathrm{g}$ egg yolk to $263.90 \pm 14.83 \mathrm{mg} / \mathrm{g}$ egg yolk in hen (Vorlova et al. 2001) which was in agreement with the present study. Egg yolk cholesterol by HPLC was 12 $\mathrm{mg} / \mathrm{g}$ egg yolk in Brazilian chicken egg (Bragagnolo et al. 2002) which was slightly lower than present observed range. Egg yolk cholesterol by gas chromatography and (Zak, 1977) procedures found was $12.07 \pm 0.06 \mathrm{mg} / \mathrm{g}$ in egg yolk (Rowghani et al. 2007) which was similar to the present estimated value. Egg yolk concentration by enzymatic method (Colestat Enzymatic kit, Wiener lab, Argentina) after lipid extraction was $0.65 \mathrm{~g} / 100 \mathrm{~g}$ egg yolk in eggs of Araucana hen (Gultemirian et al. 2009) which was lower than the present observed range. Egg yolk cholesterol by gas

Table 1: Standard layer feed (Crumegg-1).

\begin{tabular}{lc}
\hline Ingredient & Standard layer feed (Crumegg-1) \\
\hline Moisture (Maximum) & $10.00 \%$ \\
Crude protein (Minimum) & $18.00 \%$ \\
Crude fibre (Maximum) & $6.00 \%$ \\
Crude fat (Minimum) & $3.00 \%$ \\
Calcium (Minimum) & $3.50 \%$ \\
Phosphorus (Minimum) & $0.40 \%$ \\
Metabolic energy (Minimum) & $2800 \mathrm{Kcal} / \mathrm{kg}$ \\
\hline
\end{tabular}


Table 2: Cholesterol values in $\mathrm{mg} / \mathrm{egg}$ yolk, cholesterol values in $\mathrm{mg} / \mathrm{ml}$ egg yolk and yolk volume $(\mathrm{ml})$.

\begin{tabular}{|c|c|c|}
\hline $\begin{array}{l}\text { Cholesterol in } \\
\mathrm{mg} / \mathrm{egg} \text { yolk }\end{array}$ & $\begin{array}{l}\text { Cholesterol in } \\
\mathrm{mg} / \mathrm{ml} \text { in egg yolk }\end{array}$ & $\begin{array}{c}\text { Yolk volume } \\
\text { (ml) }\end{array}$ \\
\hline 172.12 & 13.24 & 13.0 \\
\hline 188.10 & 12.54 & 15.0 \\
\hline 160.68 & 12.36 & 13.0 \\
\hline 208.63 & 13.46 & 15.5 \\
\hline 191.70 & 12.78 & 15.0 \\
\hline 167.04 & 13.92 & 12.0 \\
\hline 187.04 & 13.36 & 14.0 \\
\hline 204.48 & 12.78 & 16.0 \\
\hline 174.72 & 12.48 & 14.0 \\
\hline 179.82 & 13.32 & 13.5 \\
\hline 186.60 & 12.44 & 15.0 \\
\hline 186.31 & 12.02 & 15.5 \\
\hline 214.20 & 12.60 & 17.0 \\
\hline 204.80 & 12.80 & 16.0 \\
\hline 214.08 & 13.38 & 16.0 \\
\hline 219.84 & 13.74 & 16.0 \\
\hline 189.00 & 12.60 & 15.0 \\
\hline 222.12 & 12.34 & 18.0 \\
\hline 227.24 & 11.96 & 19.0 \\
\hline 186.30 & 12.42 & 15.0 \\
\hline 166.32 & 11.88 & 14.0 \\
\hline 188.48 & 11.78 & 16.0 \\
\hline 175.20 & 11.68 & 15.0 \\
\hline 181.20 & 12.08 & 15.0 \\
\hline 176.39 & 11.38 & 15.5 \\
\hline 177.30 & 11.82 & 15.0 \\
\hline 199.20 & 13.28 & 15.0 \\
\hline 184.73 & 12.74 & 14.5 \\
\hline 193.44 & 12.48 & 15.5 \\
\hline 192.60 & 12.84 & 15.0 \\
\hline 192.30 & 12.82 & 15.0 \\
\hline 215.90 & 12.70 & 17.0 \\
\hline 215.22 & 12.66 & 17.0 \\
\hline 240.84 & 13.38 & 18.0 \\
\hline 220.32 & 12.96 & 17.0 \\
\hline 224.40 & 13.20 & 17.0 \\
\hline 213.18 & 12.54 & 17.0 \\
\hline 189.12 & 12.61 & 15.0 \\
\hline 196.16 & 12.26 & 16.0 \\
\hline 190.40 & 11.90 & 16.0 \\
\hline 187.24 & 12.08 & 15.5 \\
\hline 224.68 & 12.48 & 18.0 \\
\hline 191.68 & 11.98 & 16.0 \\
\hline 208.00 & 13.00 & 16.0 \\
\hline 175.50 & 11.70 & 15.0 \\
\hline
\end{tabular}

Mean \pm standard error of cholesterol in $\mathrm{mg} / \mathrm{egg}$ yolk $=195.66 \pm 2.80$ $\mathrm{mg} / \mathrm{egg}$ yolk, of cholesterol in $\mathrm{mg} / \mathrm{ml}$ in egg yolk $=12.59 \pm 0.09 \mathrm{mg} /$ $\mathrm{ml}$ egg yolk and of yolk volume in $\mathrm{ml}=15.54 \pm 0.21 \mathrm{ml}$. chromatography was $341 \mathrm{mg} / 100 \mathrm{~g}$ egg yolk in conventional eggs and $489 \mathrm{mg} / 100 \mathrm{~g}$ egg yolk in organic eggs (Matt et al. 2009) which was lower than the present observed range. Egg yolk cholesterol determined by using the described method in Biochemical Analysis and Food Analysis was $20.27 \mathrm{mg} / \mathrm{g}$ egg yolk in laying hen egg (Canogullari et al. 2009) which was higher than the present observed range.

Egg yolk cholesterol by HPLC method and colorimeter method was $12.71 \pm 1.54 \mathrm{mg} / \mathrm{g}$ and $12.17 \pm 1.36 \mathrm{mg} / \mathrm{g}$, respectively in chicken egg yolk (Aquino et al. 2010). Egg yolk cholesterol by gas chromatography using a polar capillary column was $120-193 \mathrm{mg} / \mathrm{egg}$ (Naviglio et al. 2012) which was within the present observed range. Egg yolk cholesterol estimated by (Allain et al.1974) method was $12.06 \pm 0.71 \mathrm{mg} /$ $\mathrm{g}$ egg yolk in village hen egg and as $13.02 \pm 0.69 \mathrm{mg} / \mathrm{g}$ egg yolk in broiler egg (Jeyamala and Thangadurai, 2018) which was within the present observed range.

\section{CONCLUSION}

The results concluded that the value of total cholesterol obtained by this methodology was accurate and specific. Such information will be helpful to the consumers for the consumption of lower cholesterol eggs as well as helpful to farmers to compare and choose suitable breed for poultry farming under semi intensive system and for better marketability of eggs.

\section{REFERENCES}

Allain, C.C., Poon, L.S., Chan C.S.G., Richmond, W. and Fu, P.C. (1974). Enzymatic determination of total serum cholesterol. Clinical Chemistry. 20: 470-475.

Arntz, H.R., Leonhardt, H. and Dreykluft, H.R. (1979). Influence of clofibrate on blood viscosity in primary hyperlipoproteinemia. Klin Wochenschr. 57: 43-50.

Aquino, J.D.S. and Joao, A.D.S. (2010). Total lipids, cholesterol and fatty acid composition of ostrich eggs. Rev. Inst. Adolfo Lutz (Impr.). 69: 588-94.

Bragagnolo, N. and Rodriguez-Amaya, D.B. (2002).

Comparison of the cholesterol content of Brazilian chicken and quail eggs. Journal of Food Composition and Analysis. 16: 147-153.

Canogullari, S., Karaman, M., Erdogan, Z., Baylan, M., Kucukgul, A., Duzguner, V. and Ozugur, A. (2009). Effect of garlic powder on egg yolk and serum cholesterol and performance of laying hens. Bulletin of the Veterinary Institute in Pulawy. 53: $515-519$.

Flegg, H.M. (1973). An investigation of the determination of serum cholesterol by an enzymatic method. Annals of Clinical Biochemistry. 10: 79-84.

Folch, J., Lees, M. and Sloane-Stanley, G.H. (1957). A simple method for the isolation and purification of total lipids from animal tissues. Journal of Biological Chemistry. 226: 497-509.

Gultemirian, M.L., Van Nieuwenhove, C., Pérez Chaia, A., and Apella, M.C. (2009). Physical and chemical characterization of eggs from Araucana hens of free range fed in Argentina. Journal of the Argentine Chemical Society. 97: 19-30. 
Jeyamala, M. and Thangadurai, M. (2018). Biochemical analysis of two different birds egg. World Journal of Science and Research. 3: 51-55.

Kundu, A., Singh, D.P., Mohapatra, S.C., Dash, B.B., Moudgal, R.P. and Bisht, G.S. (1999). Antibody response to sheep erythrocytes in Indian native vis-à-vis imported breeds of chickens. British Poultry Science. 40: 40-43.

Matt, D., Veromann, E. and Luik, A. (2009). Effect of housing systems on biochemical composition of chicken eggs. Agronomy Research. 7(Special Issue II): 662-667.

Maurice, D.V., Lightsey, S.F., Hsu, K.T., Gaylord, T.G. and Reddy, R.V. (1994). Cholesterol in eggs from different species of poultry determined by capillary GLC. Food Chemistry. 50: 367-372.

Naviglio, D., Gallo, M., Grottaglie Le, L., Scala, C., Ferrara, L. and Santini, A. (2012). A determination of cholesterol in Italian chicken eggs. Food Chemistry. 132: 701-708.

Nielsen, H. (1998). Hen age and fatty acid composition of egg yolk lipid. British Poultry Science. 39:53-56.
Panda, A.K., Rao, S.V.R., Raju, M.V.L.N., Niranjan, M. and Reddy, M.R. (2012). Effect of nutrient density on production performance, egg quality and humoral immune response of brown laying (Dahlem Red) hens in the tropics. Tropical Animal Health and Production. 44: 293-299.

Siedel, J., Schlumberger, H., Klose, S., Ziegenhorn, J. and Wahlefeld, A.W. (1981). Improved reagent for the enzymatic determination of serum cholesterol. Journal of Clinical Chemistry and Clinical Biochemistry. 19: 838.

Rowghani, E., Arab, M., Nazifi, S. and Baktiari, Z. (2007). Effect of canola oil on cholesterol on egg-yolk of laying hens. International Journal of Poultry Science. 6: 111-114.

Vorlova, L., Sieglova, E., Karpiskova, R. and Kopriva (2001). Cholesterol content in eggs during the laying period. Acta Veterinaria Brno. 70: 387-390.

Washburn, K.W. and Nix, F. (1974). A rapid technique for extraction of yolk cholesterol. Poultry Science. 53: 1118-22.

Washburn, K.W. (1989). A modification of the Folch method of lipid extraction for poultry. Poultry Science. 68: 1425-27.

Zak, B. (1977). Cholesterol methods: A review. Clinical Chemistry. 23: 1201. 